\title{
Habitual entrepreneurs in the making: how labour market rigidity and employment affects entrepreneurial re-entry
}

\author{
Kun Fu • Anne-Sophie Larsson • Karl Wennberg
}

\begin{abstract}
We investigate the impact of country-level labour market regulations on the re-entry decision of experienced entrepreneurs, whereby they become habitual entrepreneurs. Multilevel logit models on entry decisions among 15,709 individuals in $29 \mathrm{Eu}-$ ropean countries show that labour market regulations have a positive influence on the decision to re-enter into entrepreneurship. This positive impact is stronger among individuals holding wage jobs at the time of re-entry compared to those that do not. Our results indicate that novice and habitual entrepreneurs may respond very differently to labour market rigidity. We discuss and provide tentative explanations for these differences and outline potential policy implications.
\end{abstract}

Electronic supplementary material The online version of this article (https://doi.org/10.1007/s11187-018-0011-y) contains supplementary material, which is available to authorized users.

K. Fu

Loughborough University, London, UK

e-mail: k.fu@lboro.ac.uk

A.-S. Larsson

Ratio Institute, Stockholm, Sweden

e-mail: anne-sophie.larsson@ ratio.se

K. Wennberg $(\triangle)$

Linköping University, Linköping, Sweden

e-mail: karl.wennberg@liu.se
Keywords Habitual entrepreneurship · Employment . Labour market rigidity $\cdot$ Institutional context $\cdot$ Multilevel modelling

JEL classifications $\mathrm{J} 24 \cdot \mathrm{J} 41 \cdot \mathrm{K} 31 \cdot \mathrm{L} 26$

\section{Introduction}

Entrepreneurship is not necessarily a one-off activity. An important group of entrepreneurs is those that have some form of prior start-up experience. These are often called 'habitual entrepreneurs', defined as those who have established at least one other business prior to the current one (Birley and Westhead 1993). Within this category, further classifications such as 'portfolio' and 'serial' entrepreneurs have been used to describe entrepreneurs managing one or multiple businesses at a time (Parker 2013). ${ }^{1}$ Habitual entrepreneurship is a sizeable and pervasive phenomenon, suggested by Ucbasaran et al. (2008) to comprise about 12 to $52 \%$ of entrepreneurial endeavours in the UK, about 51 to $64 \%$ in the USA, $49 \%$ in Australia, 40 to $50 \%$ in the Nordic countries, and $39 \%$ in Malaysia. Looking at the sub-group of serial entrepreneurship, studies have revealed that it accounts for 18 to $30 \%$ of the entrepreneurial activity in Europe (Westhead and Wright 1998; Westhead et al. 2005;

\footnotetext{
${ }^{1}$ In the academic literature, 'serial entrepreneurs' are sometimes de-
} fined analogously to habitual entrepreneurs. 
Plehn-Dujowich 2010). ${ }^{2}$ These entrepreneurs are of particular importance since they have been found to be more likely to identify valuable opportunities (Shane 2003; Ucbasaran et al. 2003), demonstrate higher growth expectations (Westhead et al. 2005), and generate better economic returns (Toft-Kehler et al. 2014) than novice entrepreneurs. Economic and managerial studies alike suggest that these advantages accrue due to 'learning by doing' (Toft-Kehler et al. 2014; Lafontaine and Shaw 2016) since entrepreneurial skills are difficult to learn before to entry.

Although many differences have been identified between novice and experienced entrepreneurs in terms of their demographics (Westhead and Wright 1998), attitudes (McGrath and MacMillan 2000), and behaviours (e.g. Wiklund and Shepherd 2008), there are few systematic studies on how the institutional context affects the re-entry decision of experienced entrepreneurs. This is an important gap in the literature since habitual entrepreneurs are often heralded as the ones most likely to attract external equity and scale their ventures into fast-growing companies (Toft-Kehler et al. 2014; Lafontaine and Shaw 2016). The lack of attention to external contingencies such as prevailing institutions and regulations in studies of habitual entrepreneurship is problematic since they are arguably more generalizable than more heterogeneous individualspecific factors. Further, institutional determinants of habitual entrepreneurship ought to be of particular interest to policy makers seeking to enhance not only the quantity but also the quality of entrepreneurial endeavours in the economy (Henrekson and Johansson 2008; Shane 2009).

Departing from a career choice perspective on entrepreneurship, we model habitual entrepreneurship as an occupational choice embedded within the context of prevailing labour market regulations at the country level (Kim et al. 2016). Such regulations can, at least in the short term, ${ }^{3}$ have great impact on the rate of job creation

\footnotetext{
${ }^{2}$ The shares range from 12 to $27 \%$ in our sample of European countries based on Global Entrepreneurship Monitor (GEM) data (see Table 2). As GEM does not provide information on whether individuals are simultaneously running multiple firms, we cannot distinguish serial and portfolio entrepreneurs. Our sample is comprised of founders with prior entrepreneurial experience, and as such, it largely covers serial entrepreneurship. However, since we cannot effectively exclude 'portfolio entrepreneurship', we use the term 'habitual entrepreneurship'.

${ }^{3}$ Economic literature, referenced later on in this paper, shows that labour market regulations tend to affect firing, hiring, and job reallocation and that regulatory changes can affect productivity, job creation, as well as (un)employment rates. These effects may, however, not be persistent over time.
}

and unemployment of an economy, labour productivity and social protection of employees, and costs and profits of employers (Betcherman et al. 2001). Whilst earlier empirical evidence on the relationship between labour market regulation and entrepreneurship is somewhat dispersed (Román et al. 2011), ${ }^{4}$ several recent studies have shown that stringent labour market regulations decrease individuals' likelihood of becoming entrepreneurs (Van Stel et al. 2007; Bosma 2009; Bosma and Schutjens 2009; Ardagna and Lusardi 2010).

Under this framework, we ask how is the re-entry decision into entrepreneurship of an individual with prior start-up experience affected by the rigidity of labour market regulations at the country level? We further explore whether this effect has a consistent pattern across different employment statuses, as a significant amount of individuals choose to become entrepreneurs whilst retaining their wage jobs (Folta et al. 2010). We argue that labour market rigidity influence the reentry of experienced entrepreneurs and, furthermore, that the magnitude of this influence depends on the work status of an individual at the moment of re-entry. Employed individuals will respond differently to regulatory rigidity primarily because the costs and benefits from occupational changes differ from those that are not employed (Amit et al. 1995). Whilst being employed results in higher opportunity costs than not being employed when re-entering into entrepreneurship, having a job upon entry may also serve to alleviate liquidity constraints (Petrova 2012) and may signal ability since foregoing paid employment under strict labour market regulations is a decision likely to be well thought through (Bublitz et al. 2015). We suggest that these factors make employed ex-entrepreneurs more likely to become habitual entrepreneurs. Supportive of these arguments, we find the effect of stringent labour market regulations to be stronger among those who hold a salaried job upon re-entry. The more rigid the regulations, the larger the difference in re-entry likelihood of employed and non-employed individuals is.

We employ multilevel modelling to test our hypotheses drawing upon several large-scale datasets from national surveys on entrepreneurship. We use the GEM Adult Population Survey (APS) for individual-

\footnotetext{
${ }^{4}$ See, for instance, Román et al. (2011) for a review of earlier findings on the effects of employment protection legislation and Nyström (2014) for a review of studies that have more widely studied the effects of regulations on entrepreneurship.
} 
level data and the World Bank's Ease of Doing Business (WBEDB) dataset on employment rigidity for nationallevel data on labour market regulation. Both samples cover the period from 2006 to 2010. From the GEM survey, we focus on all individuals with prior entrepreneurial experience, in a total of 15,709 observations from 29 European countries.

Our study contributes to the entrepreneurship research in the following ways. First, we explore the nuances by which institutional constraints such as labour market regulations may affect various types of entrepreneurship in differing ways, explicitly focusing on individuals with prior entrepreneurial experiencefrequently depicted as high-potential entrepreneurs. Second, we show that the effects of such contextual barriers on the macro level may be contingent on individuals' work status, in this case, whether exentrepreneurs enter from paid employment or not. Third, our study provides nuance to the occupational choice literature, which, by and large, has viewed wage work and self-employment as discrete choices, overlooking the importance of individuals who enter into entrepreneurship whilst concurrently in employment (Burke et al. 2008; Folta et al. 2010; Petrova 2012). We contribute to this stream of literature by demonstrating how these 'hybrid entrepreneurs' may be differently affected by the prevailing labour market regulations in their society (Schulza et al. 2016).

\section{Theory and hypotheses}

\subsection{Entrepreneurship as a career choice}

Economists, sociologists, and management scholars alike have for long modelled individuals' entrepreneurship from the perspective of their occupational choice (Lucas Jr 1978; Douglas and Shepherd 2002; PlehnDujowich 2010; Burton et al. 2016). This perspective can be understood as "the vocational decision process in terms of the individual's decision to enter an occupation as a wage or salaried individual or a self-employed one" (Katz 1992, p. 30).

Studies rooted in the economic literature regard career choices as based on the trade-off between relative costs and benefits associated with different career options. When faced with several occupational options, individuals tend to choose a job (e.g. employment or self-employment) that can maximize their economic and non-economic utility. Individuals will choose entrepreneurship if the expected utility of self-employment exceeds that of other options (Douglas and Shepherd 2000, 2002; PlehnDujowich 2010). This decision has also been shown to be affected by factors such as individuals' psychological attributes and skills (Lazear 2004; Parker 2009; Åstebro and Thompson 2011), social networks (Katz 1992), and human capital (Shane 2003). The movement between entrepreneurship and paid employment has, furthermore, been proven quite common. Instead of being treated as an end state (Earle and Sakova 2000), entrepreneurial career choice has increasingly been investigated from a transition and mobility angle (Douglas and Shepherd 2002; Sørensen and Fassiotto 2011), where individuals can switch between different occupational options. For example, a potential entrepreneur may decide to take on a salaried job following a utility-maximising strategy and switch to selfemployment once it emerges as the best option at a given time (e.g. a good opportunity appears, funding key partners or personnel becomes available) (Douglas and Shepherd 2002). If entrepreneurship becomes less beneficial and rewarding, the entrepreneur may consider leaving the current venture and seek employment at an established firm (Burton et al. 2016). Habitual entrepreneurship can, in part, be viewed as an outcome of this process.

To date, few studies have explicitly modelled the occupational choice of habitual entrepreneurs. In a formal model, Plehn-Dujowich (2010) argues that entrepreneurial skills and business quality are complementary to each other. High-skilled entrepreneurs become serial entrepreneurs through constantly looking for high-quality ventures that generate a high expected value (profit), whilst low-skilled ones will not become serial entrepreneurs. However, such a formal model does not square very well with the existing evidence where low-skilled individuals often seem to be driven out of the labour market and therefore engage in multiple or serial necessity-driven entrepreneurial activities (Gottschalk et al. 2017). Parker (2014) developed a more comprehensive career choice model that allowed for the possibility that individuals may explore multiple entrepreneurial opportunities at the same time. The current study builds upon and extends this line of discussion by including the situation where employment and entrepreneurial opportunities are pursued simultaneously. 
2.2 Labour market regulation and entrepreneurial career choice

Institutional economics depicts labour market institutions as parts of the 'rules of the game' for conducting business, regulating the costs and benefits of certain economic activities. Entrepreneurs as economic actors are embedded within this context. Research has shown that economic, political, or sociocultural conditions at the national level influence individuals' decisions of whether and how to pursue entrepreneurial opportunities (Levie and Autio 2011; Urbano and Alvarez 2014) and that a favourable institutional context increases the incidence of highquality entrepreneurship that has great potential of contributing to the society (Baumol 1990; Henrekson and Johansson 2008, 2010; Autio and Fu 2015).

Labour market regulations cover a wide range of rights and responsibilities of the parties involved in the labour market for the purpose of efficiency or equity. Such regulations can have great impact on the rate of job creation and unemployment of an economy, labour productivity and social protection of employees, as well as cost and profits of employers (Betcherman et al. 2001).

The economic literature on the effects of labour market regulations, ${ }^{5}$ especially on hiring and firing and (un)employment, is vast. Stringent employment protection has been argued to stabilize employment, perhaps especially through reducing firings in recessions. Empirical studies have shown that regulatory stringency tends to be associated with less turnover and job reallocation (Von Below and Thoursie 2010; Bassanini and Garnero 2013).

Stringent labour market regulations have also been argued to deter firm growth and job creation (Pierre and Scarpetta 2004; Henrekson et al. 2010), and empirical findings show that increased regulatory flexibility, at least in the short term, can have a job-creating effect (Boeri and Garibaldi 2007) and increase productivity (Autor et al. 2007; Bassanini et al. 2009). The empirical evidence on the relationship between labour market regulation and entrepreneurship is, however, relatively sparse. We conducted a literature review by keyword searches and summarize the recent studies using comparable data in Table 1.

Table 1 shows that, with somewhat varying results, all of the recent studies that utilize the GEM data

\footnotetext{
$\overline{5}$ Often measured in terms of 'employment protection legislation'
}

indicate that stringent labour market regulations can have negative effects on entrepreneurial activity. Using the GEM data for 39 countries during the years 20022005, Van Stel et al. (2007) found a strong negative effect of stringent labour market regulations - in terms of rigidity of employment and rigidity of hours - on entrepreneurship rates. A study by Bosma and Schutjens (2009) on Dutch regions found that labour protection has strong adverse effects on the level of growth-oriented entrepreneurship but found no effect on 'low growth-oriented early-stage entrepreneurship activity'. 6 In another study, Bosma (2009) found a strong negative relationship between employment protection and growth-oriented entrepreneurship, but no significant effects on low-growth-oriented entrepreneurship, using a similar multilevel methodology as in the current paper. Ardagna and Lusardi (2010) used the GEM data for 37 predominantly high-income countries in 2001-2002 and found that labour market regulations curtail the otherwise strong and positive effects of social networks, especially for opportunity entrepreneurs.

These results are in line with earlier findings that have shown that stringent labour market regulation can decrease individuals' likelihood of becoming entrepreneurs as the earning risk in self-employment is much higher than that in paid employment (Parker 1997). All of the studies that we have surveyed have studied either novice or nascent and, sometimes, young, entrepreneurial activity. ${ }^{7}$ Distinctions based on motivation (opportunity or necessity) and growth aspirations (high or low) are frequent, but to the best of our knowledge, no previous study has singled out the effects of labour market regulations on habitual entrepreneurs.

Given the sparsity of empirical literature on the potential effects of labour market rigidity on individuals' likelihood of re-entering into entrepreneurship, we turn to the general economic literature on the effects of employment protection as guidance for theorising. This literature suggests that higher labour market rigidity may lead to increased hiring costs and more complex recruitment processes: increasing the requirements for

\footnotetext{
${ }^{6}$ Mostly European NUTS-1, and in some instances NUTS-2, NUTS-3, or RORs (Germany), was also included.

${ }^{7}$ A study by Bjørnskov and Foss (2008) used the 2001 wave of GEM data to investigate the relationship between regulations and entrepreneurship and found no statistically significant effects using a compounded 'regulatory quality' variable composed of three subindices of the Economic Freedom of the World index. It should be noted that the 2001 GEM data is known to be rather unreliable compared to subsequent years.
} 


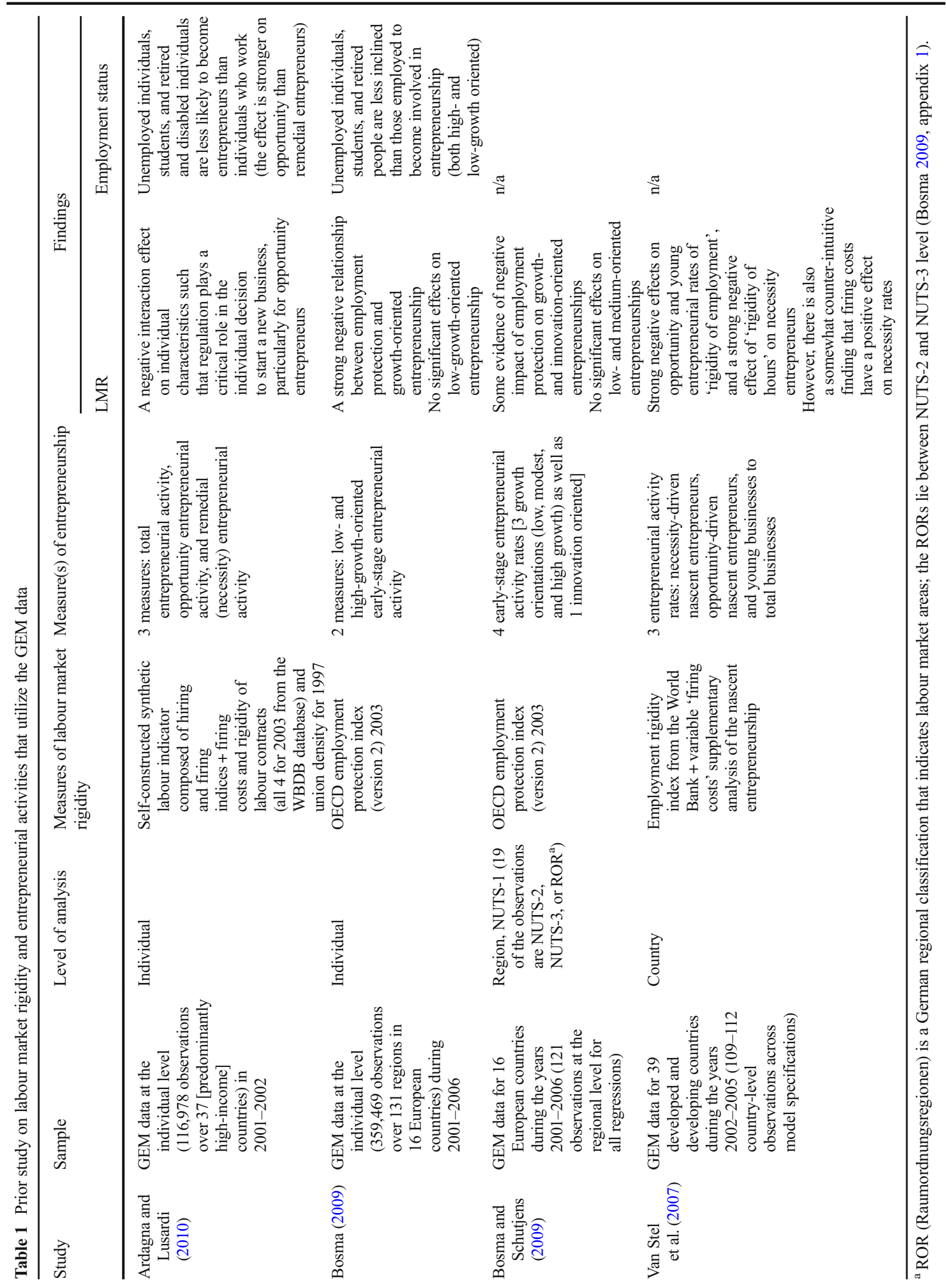


employment and dampening the demand for labour (Autor et al. 2007), effectively raising the thresholds for, and decreasing the probability of, attaining paid employment (Lindbeck and Snower 1986).

Individuals with entrepreneurial experiences often have career breaks due to having taken time off to develop their own business (Hyytinen and Rouvinen 2008). The relevance and consistency of their work experiences can therefore sometimes be called into question when they try to make a shift from selfemployed to wage earners. Entrepreneurs tend to be characterised as 'jacks-of-all-trades' with a balanced skill set (Lazear 2004), a feature that potential employers may, however, equate with a lack of specialisation and expertise (Åstebro and Thompson 2011). Employers may also shun individuals with entrepreneurial experiences as potentially difficult to retain, effectively deterring them from hiring ex-entrepreneurs in the first place. Consequently, the search costs of a wage employment for individuals with entrepreneurial experience increase substantially.

These theoretical mechanisms are likely to be exacerbated by rigid regulations that make employers 'err on the side of caution'. The stricter the labour market regulations, the more likely former entrepreneurs are to be excluded from employment opportunities, increasing their likelihood to enter self-employment again, effectively becoming habitual entrepreneurs. We thus propose

Hypothesis 1: Among individuals with entrepreneurial experiences, high country-level labour market rigidity increases individuals' likelihood of entrepreneurial re-entry.

\subsection{Entrepreneurship and concurrent employment status}

Occupational choices are, however, not mutually exclusive. Occupational choice theory tends to assume that individuals will choose between paid employment, selfemployment, or unemployment one at a time depending on the cost and benefit associated with each occupational option (i.e. Douglas and Shepherd 2002). However, people have been shown to often start a new business whilst retaining a wage-earning job. When possible, retaining a salaried job whilst engaging in an entrepreneurial activity provides people with complementary income and offers the possibility to learn more about the new venture and the personal fit with the new business whilst minimising sunk cost (Folta et al. 2010; Raffiee and Feng 2014). Stable income from employment allows individuals to have a transition stage from part-time to full-time entrepreneurship and may serve to alleviate liquidity constraints in the early stage of the new venture (Colombo and Grilli 2007; Petrova 2012; Frid et al. 2016). Furthermore, having paid employment sends signals of ability which is important for potential stakeholders when launching a new venture (Bublitz et al. 2015). Empirical findings by Bosma and Schutjens (2009) and Ardagna and Lusardi (2010) support the notion that employment status plays a role in the decision of becoming an entrepreneur: unemployed individuals, students, and retired individuals are overall less likely to become entrepreneurs than employed individuals are. This rationale should be especially relevant for individuals with prior entrepreneurial experiences who have learned about the time necessary to start a new venture and the financial costs this may incur (Kim et al. 2006). We therefore propose

Hypothesis 2: Among individuals with entrepreneurial experiences, being employed, either parttime or full-time, increases individuals' likelihood of entrepreneurial re-entry.

It is also possible that employed and non-employed individuals will respond differently to the rigidity of labour market regulations when considering a potential re-entry into entrepreneurship.

Higher labour market rigidity not only increases the cost of firms hiring people but also implies increased costs for dismissals, sometimes equated to a tax on firing (Autor et al. 2007). Faced with such costs, dismissals tend to become less frequent and the demand for labour dampened, at least in the short run. As such, stringent employment protection is often associated with lower productivity, especially when it comes to the regulatory rigidity of regular contracts (Bassanini et al. 2009). Strict employment protection could thus offer employed individuals the opportunity to, at least temporarily, decrease their job effort without great risk of being laid off, fostering a beneficial situation for early-stage hybrid entrepreneurship. This effect is also likely to be exacerbated when coupled with strong restrictions on the maximum length of working days and hours, night and weekend work, and vacation days as this 
will grant employees more flexibility to allocate their time. When overwork is restricted, people's earnings are also limited. They will try to find other ways to gain supplemental income. The more rigid the labour market regulation, the more flexibility and security the employees will gain, whilst increasing the need for supplemental income. Based on the above analyses, we propose that

Hypothesis 3: Among individuals with entrepreneurial experiences, the effect of labour market rigidity on individuals' likelihood of becoming habitual entrepreneurs depends on their employment status, such that the positive effect of regulatory rigidity is stronger for individuals holding a wage job upon entrepreneurial re-entry.

\section{Methods}

\subsection{Data and sample}

We use the GEM APS for individual-level data on entrepreneurship. The GEM is an annual survey collecting micro-individual-level data on entrepreneurial attitudes, activities, and aspirations (Reynolds et al. 2005). This database covers a yearly random sample of working-age adults (18-64 years old) in all 29 countries under investigation over the periods 2006 to 2010 . We draw the sample from the population that has indicated that they have prior entrepreneurial experience. The GEM questionnaire captures this information by asking: "Have you alone or with other, started business in the past that you owned and managed?" There are, in total, 15,709 observations included in the sample. We use the WBEDB dataset for the same time period, which records three elements of employment rigidity index: difficulty of hiring index, rigidity of hours index, and difficulty of firing index that reflect the rigidity in the regulation of employment in a given country (Botero et al. 2004).

\subsection{Variables and measures}

\subsubsection{Dependent variable}

Entrepreneurial re-entry Our dependent variable of focus is the re-entry into entrepreneurship by an individual with prior entrepreneurial experience (Birley and
Westhead 1993), measured by a dummy variable taking the value 1 for re-entry and 0 otherwise.

\subsubsection{Independent variables}

Labour market rigidity Labour market rigidity captures the flexibility in the regulations of employment in a given country. It is measured by the employment rigidity index from the WBEDB, which is based on the average value of three sub-indices: a difficulty of hiring index, a rigidity of hours index, and a difficulty of firing index, with higher values indicating more rigid labour market regulation. Similarly to Van Stel et al. (2007), who used similar variables for their country-level analysis, we rely solely on the employment rigidity index and not the three separate indices from the WBEDB since these are highly collinear.

Employment status Current main employment status or current working situation for each individual was coded into seven categories: full-time work, part-time work, unemployed, retired or disabled, student, homemaker, or other (Bosma et al. 2012). Based on the above information, individuals with prior entrepreneurial experience are grouped into one of two broader categories: those who are employed (i.e. those currently engaged in part- or full-time work) and those who are not employed (i.e. all others).

\subsubsection{Control variables}

Individual-level control variables We control for a set of individual-level variables related with one's propensity of participating in entrepreneurial activities. Age of an individual is measured in years. Gender takes the value 1 for females and 0 for males. Education takes the values of $1,2,3,4$, and 5 for individuals that have received the following: no education, primary education, secondary education, post-secondary, and graduate education, respectively. Household income takes the values of 1,2 , and 3 for the lowest-, middle-, and highest-income tiers in the population, respectively. Fear of failure indicates whether fear of failure would prevent the individual from setting up a business ( $1=$ yes, $0=$ otherwise). Entrepreneurial knowledge and skills indicates if the individual perceived himself or herself as having the required skills and knowledge to start a new business ( $1=$ yes, $0=$ otherwise). 
Country-level control variables We control for the TEA rate - the prevalence rate of total early-stage entrepreneurial activities in a country - as the relative presence of entrepreneurs likely affects individuals' likelihood of engaging in entrepreneurship (Bird and Wennberg 2014). Several macro-economic factors associated with entrepreneurial activities have been introduced into the models as control variables as they have been shown to have a significant impact on the nature of entrepreneurial activity (Autio and Fu 2015). Since a country's wealth has been shown to influence the prevalence of entrepreneurial activity, we control for GDP per capita (USD) adjusted for purchasing power parity (PPP), and annual GDP growth rate (Levie and Autio 2011). Population growth captures the growth of potential market, measured as the annual percentage population growth rate in a country. Finally, we control for the institutional effect of ease of starting a business as well as current unemployment rate, both from the World Bank datasets.

\subsection{Data analyses}

We employ multilevel regressions for testing the hypotheses due to the hierarchical structure of the dataset where individual-level observations are unevenly nested in countries (Hofmann et al. 2000). A two-level model with random intercept is specified to assess the variation in the probability of becoming a habitual entrepreneur by factoring in both the impact of labour market regulations at the country level and the influence of work status at the individual level. The model is specified as

\section{Level 1 equation:}

$Y_{i j}=\beta_{0 j}+\beta_{1 j} X_{i j}+e_{i j}$

Level 2 equation:

$\beta_{0 j}=\gamma_{00}+\gamma_{01} W_{j}+u_{0 j}$

$\beta_{1 j}=\gamma_{10}+u_{1 j}$

The level 1 equation predicts the direct effects (i.e. betas) of level 1 predictors on level 1 outcomes, where $Y_{i j}$ is the dependent variable for an individual observation at level 1. $X_{i j}$ is the individual-level (level 1) predictor where $i$ refers to the individual and $j$ to the country of residence. $\beta_{0 j}$ is the intercept of the dependent variable in country $j$ (level 2). $\beta_{1 j}$ is the slope for the relationship in country $j$ between the individual-level predictor and the dependent variable. $e_{i j}$ is the individual-level residual. The level 2 equations predict the effects (i.e. gammas) of level 2 predictors on level 1 betas as well as on the level 1 intercept, where $\gamma_{00}$ is the overall intercept, which is the mean of the intercepts across countries. $W_{j}$ is the country-level predictor. $\gamma_{01}$ is the slope or main effect of country-level predictor. $\gamma_{10}$ is the slope or main effect of individual-level predictor. $u_{0 j}$ and $u_{1 j}$ are country-level residuals.

$$
\begin{aligned}
& \text { Multilevel equation of the current study } \\
& Y_{i j}=\gamma_{00+} \gamma_{01} \text { Labor market rigidity }_{j} \\
& +\gamma_{02} \text { GDP per capita }_{j}+\gamma_{03} \text { GDP }_{\text {growth }} \\
& +\gamma_{04} \text { Population growth }_{j} \\
& +\gamma_{05} \text { Ease of starting a business }{ }_{j}
\end{aligned}
$$

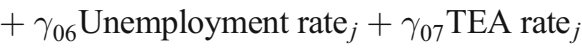

$$
\begin{aligned}
& +\gamma_{10} \text { Employment status }_{i j}+\gamma_{20} \text { Gender }_{i j} \\
& +\gamma_{30} \text { Age }_{i j}+\gamma_{40} \text { Income }_{i j}+\gamma_{50} \text { Education }_{i j} \\
& +\gamma_{60} \text { Fear of failure }{ }_{i j} \\
& +\gamma_{70} \text { Entrepreneurial skills }_{i j}+u_{0 j}+e_{i j}
\end{aligned}
$$

To facilitate the interpretation of meaningful effects, we computed average marginal effects (AMEs) for all independent variables. For continuous variables such as labour market rigidity, AMEs represent the instantaneous rate of change for the variable of interest. Since it is more informative to show the predictive margins over a set of values of variables of interest (Brambor et al. 2006), we calculated the predicted probability of the habitual entrepreneurship over a set of observed values of labour market rigidity and present the results graphically.

\section{Results}

Before zooming into our analyses, some overall trends are noteworthy to report. Descriptive statistics based on the GEM data over the periods 2001 to 2010 (overlapping our period of analysis) indicates that throughout Europe, the prevalence rate of opportunity-driven entrepreneurship (12.12\%) is nearly three times higher among individuals with prior entrepreneurial experience than the rate among 
those who have not started any business before (3.55\%). Among those currently owning and managing a business, habitual entrepreneurs are more likely to have a business with a product innovation (46.61 vs. $40.66 \%)$ and a higher growth expectation (15.66 vs. $10.03 \%)$ than the novice entrepreneurs.

Table 2 shows the average value of labour market rigidity measured across 5 years in the 29 European countries of our sample, with higher values indicating more rigid labour market regulation. In our data, France is the most rigid country in terms of labour market regulation and Denmark the most flexible.

We plotted 'caterpillar' graphs to show the countrylevel variances in habitual entrepreneurial activity
(Fig. 1), finding that the levels of habitual entrepreneurship vary significantly across the European countries. There are five countries with confidence intervals distinctly lower than 0, in particular for Denmark, France, and Belgium, and five countries with confidence intervals distinctly higher than 0 , Spain and Latvia being the most prominent ones.

Table 3 provides descriptive statistics for all the explanatory and control variables in the current study. Table 4 shows the correlation matrix for the individual-level variables and country-level controls and predictors. Variance inflation factors (VIFs) for all variables were between 1.05 and 2.57 , indicating a low risk of multicollinearity.

Table 2 Descriptive data on country-level labour market rigidity and entrepreneurial activities

\begin{tabular}{|c|c|c|c|}
\hline Country & Habitual entrepreneurship (\%) & Total early-stage entrepreneurship (\%) & Labour market rigidity (mean) \\
\hline Denmark & 0.13 & 0.05 & 3.33 \\
\hline UK & 0.18 & 0.04 & 4.04 \\
\hline Switzerland & 0.17 & 0.06 & 5.14 \\
\hline Belgium & 0.12 & 0.03 & 10.33 \\
\hline Ireland & 0.22 & 0.07 & 10.33 \\
\hline Hungary & 0.18 & 0.06 & 13.27 \\
\hline Montenegro & 0.22 & 0.15 & 13.33 \\
\hline Czech Republic & 0.15 & 0.06 & 14.44 \\
\hline Iceland & 0.25 & 0.11 & 14.98 \\
\hline Austria & 0.13 & 0.04 & 20.33 \\
\hline Russia & 0.20 & 0.04 & 27.78 \\
\hline Germany & 0.18 & 0.05 & 27.78 \\
\hline Sweden & 0.21 & 0.03 & 29.50 \\
\hline Bosnia and Herzegovina & 0.17 & 0.06 & 31.31 \\
\hline Serbia & 0.18 & 0.05 & 32.22 \\
\hline Turkey & 0.16 & 0.06 & 35.17 \\
\hline Macedonia & 0.22 & 0.09 & 35.40 \\
\hline Finland & 0.22 & 0.05 & 37.61 \\
\hline Latvia & 0.27 & 0.07 & 37.62 \\
\hline Portugal & 0.26 & 0.06 & 38.96 \\
\hline Italy & 0.12 & 0.04 & 40.04 \\
\hline Romania & 0.26 & 0.03 & 40.18 \\
\hline Netherlands & 0.19 & 0.04 & 42.22 \\
\hline Slovenia & 0.14 & 0.04 & 42.90 \\
\hline Norway & 0.22 & 0.06 & 43.01 \\
\hline Croatia & 0.23 & 0.05 & 43.67 \\
\hline Greece & 0.18 & 0.07 & 44.25 \\
\hline Spain & 0.25 & 0.06 & 49.48 \\
\hline France & 0.12 & 0.03 & 55.14 \\
\hline
\end{tabular}




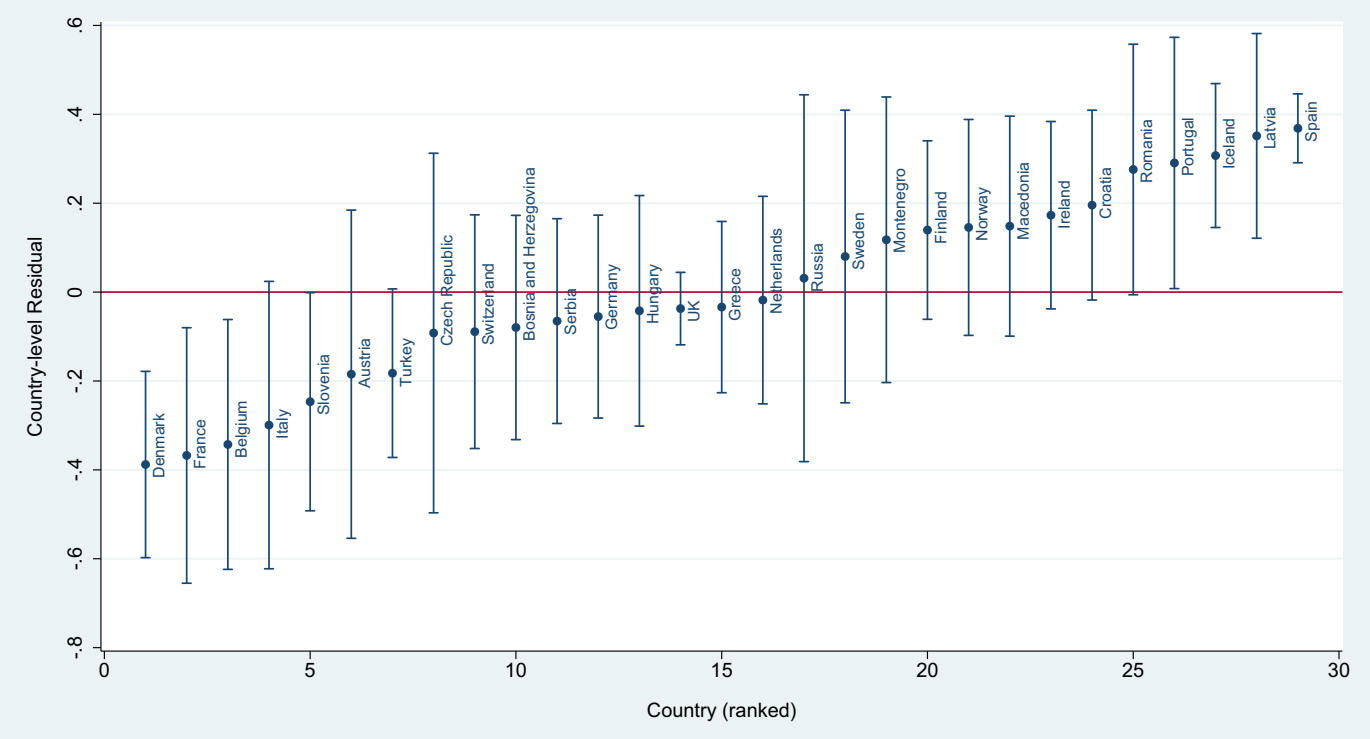

Fig. 1 Country residuals with $95 \%$ confidence intervals for habitual entrepreneurship

Table 5 shows results from the multilevel logit model. Model 1 in Table 5 is the baseline model including control variables only. Model 2 shows the main effects with key explanatory variables, and model 3 shows the cross-level interaction results.
For the main effects we find, as expected, that labour market rigidity is positively related to the probability of entrepreneurial re-entry among experienced entrepreneurs, i.e. becoming habitual entrepreneurs (odds ratios $(\mathrm{ORs})=1.173, p<0.05 ; \mathrm{AME}=0.022, p<0.05)$. This

Table 3 Descriptive statistics

\begin{tabular}{|c|c|c|c|c|}
\hline Variable & Mean & Std. Dev. & Min & Max \\
\hline Entrepreneurial re-entry & 0.20 & 0.40 & 0 & 1 \\
\hline Employed & 0.74 & 0.44 & 0 & 1 \\
\hline Labour market rigidity & 27.49 & 18.82 & 0 & 55.56 \\
\hline Gender $($ female $=1)$ & 0.40 & 0.49 & 0 & 1 \\
\hline Age & 44.67 & 11.32 & 18 & 64 \\
\hline Income 1 (middle tier) & 0.36 & 0.48 & 0 & 1 \\
\hline Income 2 (top tier) & 0.35 & 0.48 & 0 & 1 \\
\hline Education & 3.43 & 1.07 & 1 & 5 \\
\hline Fear of failure & 0.31 & 0.46 & 0 & 1 \\
\hline Entrepreneurial knowledge and skills & 0.83 & 0.38 & 0 & 1 \\
\hline TEA rate & 0.06 & 0.02 & 0.02 & 0.15 \\
\hline Log-transformed GDP per capita & 10.29 & 0.40 & 9.06 & 11.02 \\
\hline GDP growth & 1.87 & 3.20 & -17.95 & 12.23 \\
\hline Population growth & 0.75 & 0.67 & -0.55 & 2.53 \\
\hline Ease of starting a business & 81.97 & 9.42 & 58.19 & 94.08 \\
\hline Unemployment rate & 8.60 & 5.61 & 2.25 & 33.80 \\
\hline
\end{tabular}

All descriptive statistics based on $N=15,709$ 


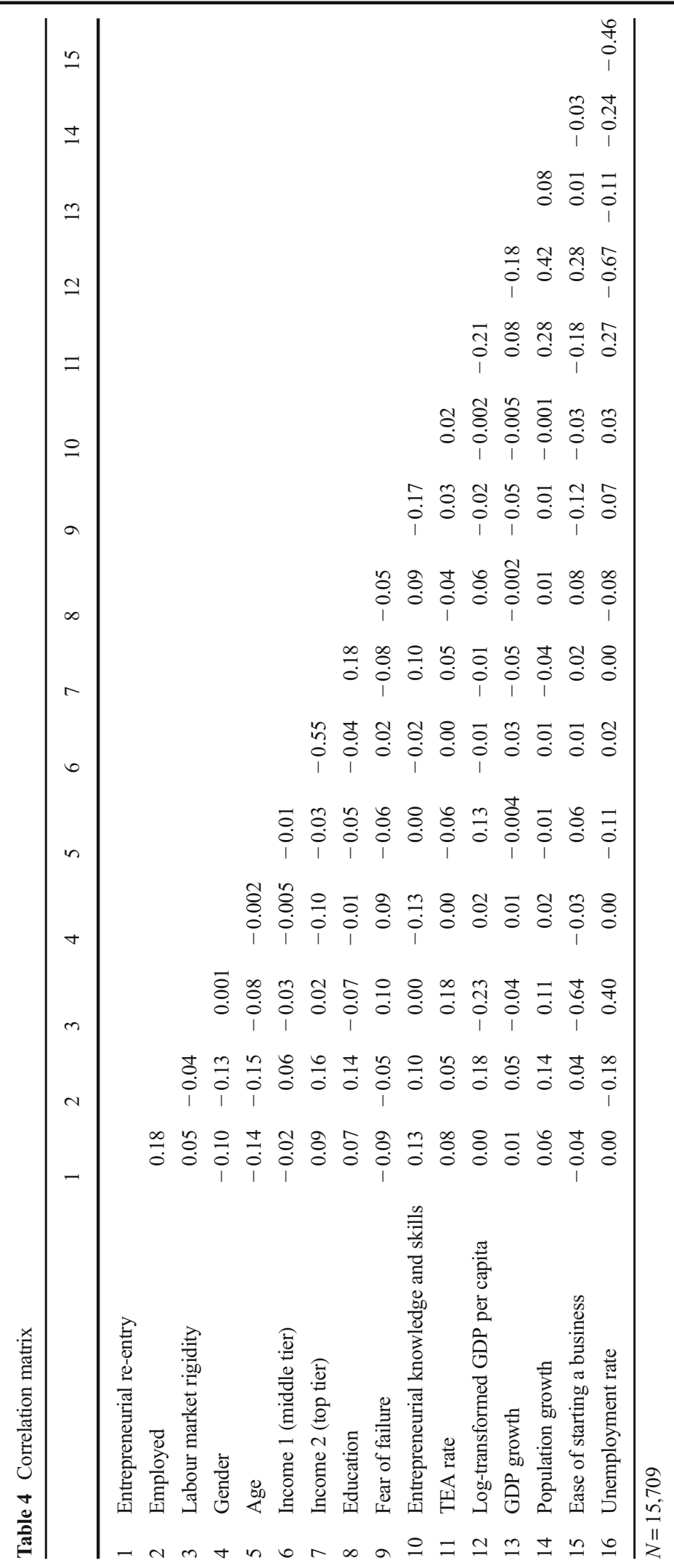




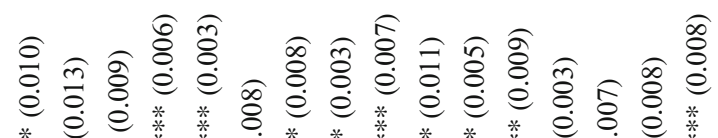

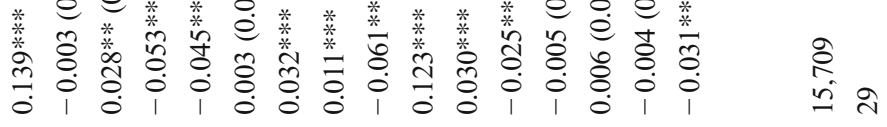

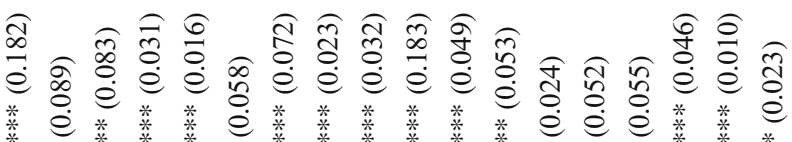

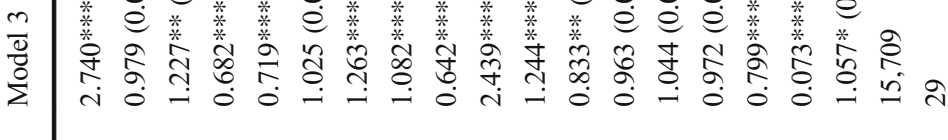

若

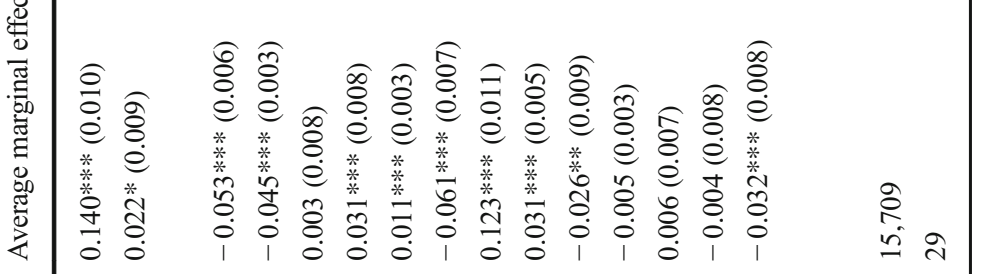

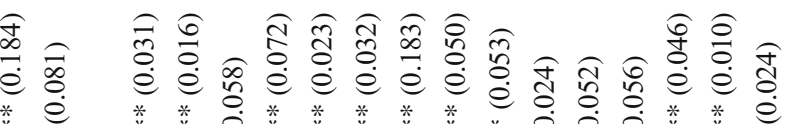

* e * *

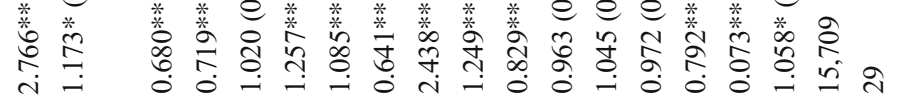

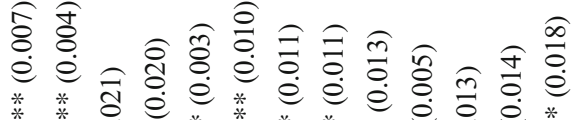

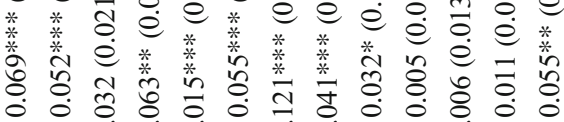

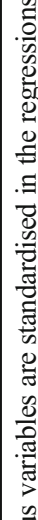

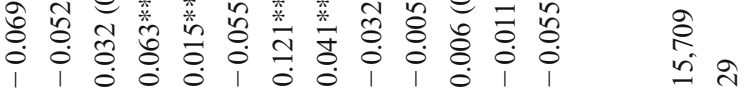

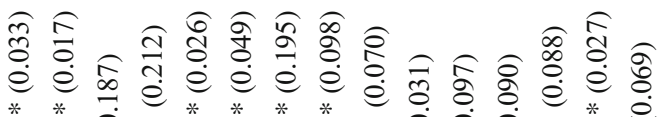

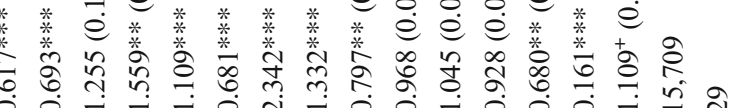

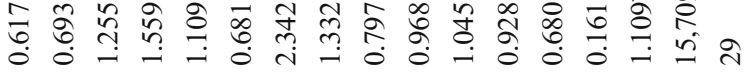

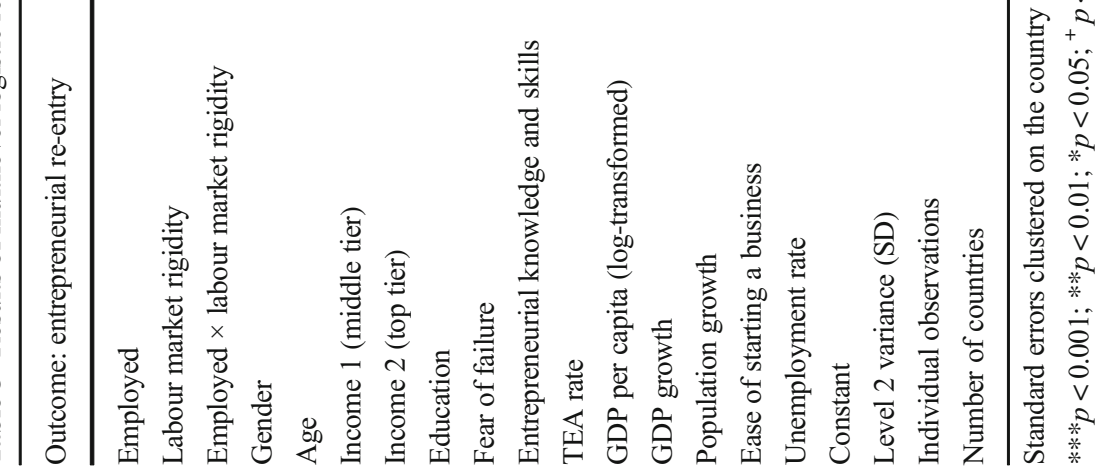


confirms hypothesis 1 in that rigid labour market regulations increase individuals' likelihood of re-engaging in entrepreneurial activity. Holding all other variables constant at their observed values, the average marginal effects of labour market rigidity increase the likelihood that experienced entrepreneurs will re-enter by $2.2 \%$.

Turning to the variable 'employment status', we find this to be positively related to the probability of entrepreneurial re-entry $(\mathrm{OR}=2.766, p<0.001)$, supportive of hypothesis 2 . Individuals holding wage jobs, either part-time or full-time, are thus more likely of becoming habitual entrepreneurs. The average marginal effects of employment status increase the likelihood that an experienced individual will again engage in entrepreneurship by $14 \%$ (AME $=0.14, p<0.001)$.

The cross-level interaction effect between countrylevel labour market rigidity and individual-level employment status is shown in model 3. This model shows that the effect of labour market rigidity on the probability of entrepreneurial re-entry depends on one's employment status $(\mathrm{OR}=1.227, p<0.01)$, meaning that under stringent labour market regulations, individuals that hold wage jobs are more likely to re-enter into entrepreneurship than those who are not employed. We present the interaction effect graphically since it varies with the values of the two interacted variables, as well as with the values of other covariates (Brambor et al. 2006). Figure 2 shows plotted predictive marginal effects of labour market rigidity at a set of observed values for individuals with or without current employment with a 95\% confidence interval, revealing that the impact of labour market rigidity on entrepreneurial re-entry is constantly stronger for employed individuals. Figure 3 shows that the differences in the predicted probability over the observed values of labour market rigidity are statistically significant between individuals with or without current employment, supporting hypothesis 3 .

\subsection{Robustness tests}

We conducted a series of robustness tests, available in the Appendix (Online Resource). We specifically examined alternative measures for labour market rigidity, split the sample into necessity and opportunity-driven habitual entrepreneurship, and examined whether entrepreneurial re-entry is dependent on previous entrepreneurial failure or success. We, furthermore, ran our models on all entrepreneurs without start-up experience in the GEM data for the same time period to accommodate an assessment of differing responses to regulatory rigidity among novice and habitual entrepreneurs, as well as to make sure that our results for novice entrepreneurs were in line with previous findings.

\section{Discussion}

Our study is among the first to focus on institutional factors shaping the entrepreneurial re-entry decisions. The results of our multilevel logit models on entry decisions among 15,709 individuals in 29 European countries show that labour market rigidity is positively
Fig. 2 Interaction effects of labour market rigidity and employment status on probability of entrepreneurial re-entry: predictive margins

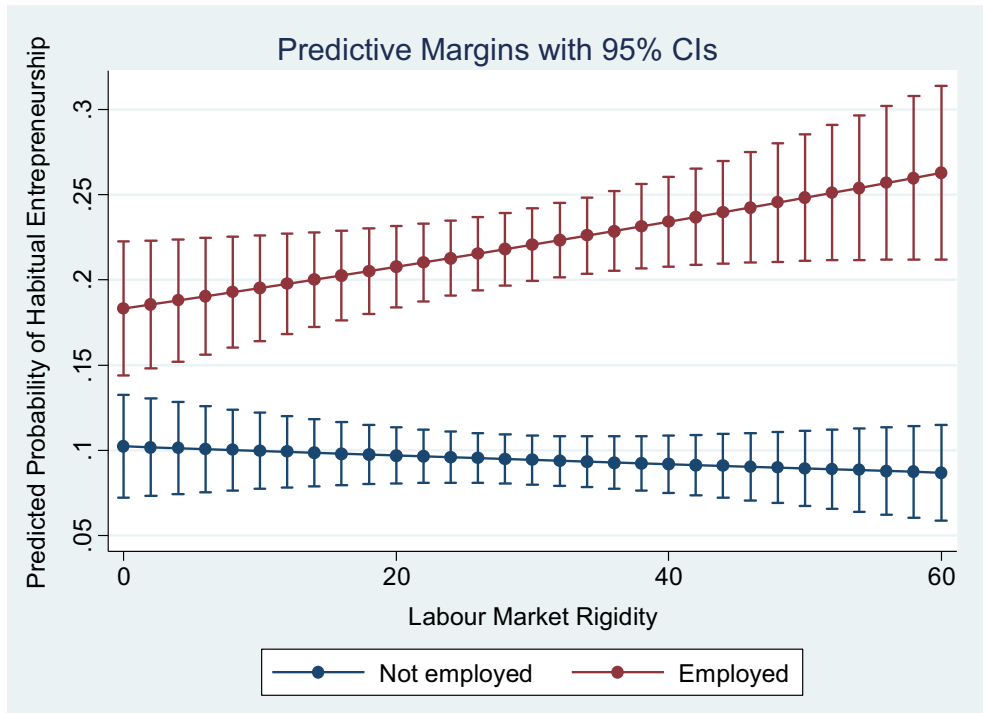


Fig. 3 Interaction effects of labour market rigidity and employment status on probability of entrepreneurial re-entry: conditional marginal effect
Conditional Marginal Effects with 95\% Cls

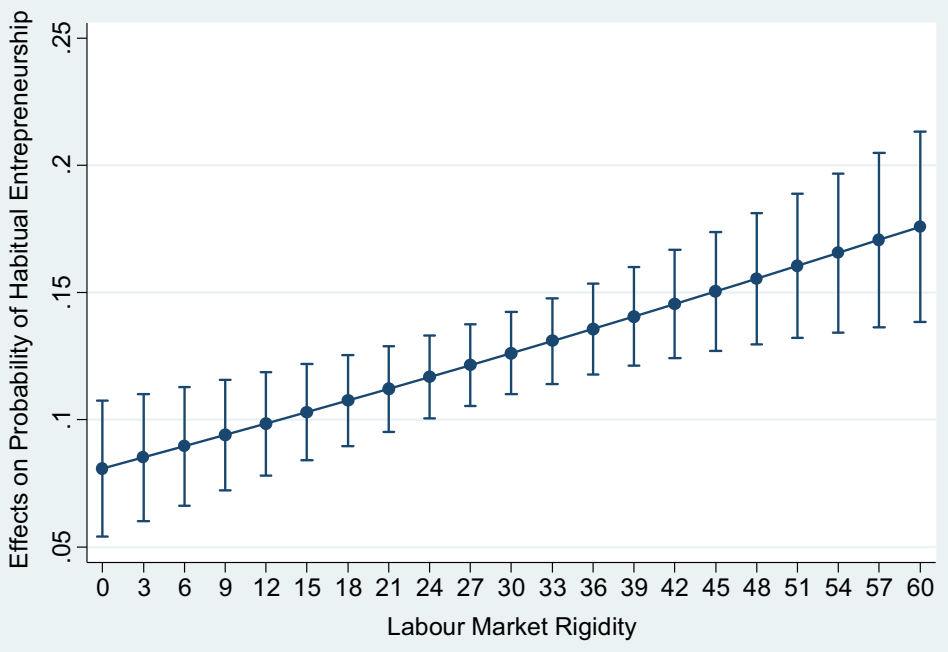

associated with re-entry into entrepreneurship. Moreover, employed individuals are more likely to make the re-entry decision under stringent labour market regulation, whilst those who are not employed at the time of re-entry are less likely to do so.

This study is, to the best of our knowledge, the first one to explicitly analyse the effects of labour market regulations on the re-entry decision of individuals' with previous entrepreneurial experience, frequently depicted as a high-potential group of entrepreneurs. We show that contextual barriers on the macro levelsuch as labour market regulations - can exert direct impact, as well as indirect impact via the labour status, on individuals' entrepreneurial re-entry decision. In doing so, the study furthers research on entrepreneurship in general and that of habitual entrepreneurs in particular, highlighting that institutional conditions may need to be incorporated in studies of entrepreneurial occupational choice. Our findings regarding the interaction between labour market regulations and employment status for ex-entrepreneurs' prospective re-entry into habitual entrepreneurship shed valuable insights on hybrid entrepreneurship and the potential importance of concurrent employment in the early stages of new firm formation (Burke et al. 2008; Folta et al. 2010; Petrova 2012). We demonstrate how these hybrid entrepreneurs may be differently affected by the prevailing labour market regulations in their society (Schulza et al. 2016).

Contrary to previous studies that have found a negative association between rigidity of labour market regulation and individuals' entrepreneurial activity, we demonstrate that there exists a positive effect of labour market rigidity on the decision to re-enter into entrepreneurship. When dividing the sample based on entrepreneurial motivations in the robustness tests, we found similar statistically significant positive effects of labour market rigidity and employment on both necessity-driven and opportunity-driven habitual entrepreneurship. Our robustness tests of the impact of labour market rigidity on the entry of novice entrepreneurs rendered quite different results: more rigid regulations have a statistically significant negative effect on opportunity-driven entrepreneurship, but no significant effect on necessity-driven entrepreneurship (although the sign was positive). The results in our robustness tests of novice entrepreneurs thus seem to be largely in line with other relatively recent findings of the effects of labour market regulations on entrepreneurship. A likely explanation for the distinct patterns of the effects of labour market regulation on novice and habitual entrepreneurship may be that opportunity-seeking individuals with prior entrepreneurial experience are equipped with greater knowledge, skills, and confidence in identifying potential opportunities and making the reentry decision, compared to those pursuing their very first ventures. Still, among those with prior experience, there is also a sizeable body of necessity-driven entrepreneurs who may be forced to re-enter into entrepreneurship due to the high 
thresholds for obtaining paid employment in labour markets with rigid regulations.

\subsection{Policy implications}

Our results come with both theoretical and policy implications: in economies with rigid labour market regulations, ex-entrepreneurs could be 'punished' and thus forced to engage in necessity-driven entrepreneurship due to higher barriers re-entering into employment. Such a pattern would be consistent with other European evidence suggestive of entrepreneurial experience not being seen favorable by employees (Hyytinen and Rouvinen 2008).

In contrast with the negative impacts of labour market regulations on high-potential or high-quality entrepreneurship found by other studies, our study has shown that labour market regulations play a surprisingly positive role in driving ex-entrepreneurs to explore good opportunities again, becoming opportunity-driven habitual entrepreneurs. Knowledge and skills acquired through prior entrepreneurial experiences may help them to more effectively identify emerging opportunities for high-potential businesses (Westhead et al. 2015), as well as foresee and more thoroughly understand the potential risks and costs associated with creating a new venture (Sarasvathy et al. 2013). Holding a salaried job upon entry is a way to reduce opportunity cost and alleviate potential liquidity constraints when launching a new venture (Folta et al. 2010; Raffiee and Feng 2014). The relative importance of having a job upon entry is, however, likely to depend both on the rigidity of labour market regulations and on the capital market available for entrepreneurs (Delmar et al. 2011).

There is also the possibility that (mis)perceptions of regulatory stringency, rather than actual regulatory stringency, may affect novice and habitual entrepreneurs differently. By analysing survey data from 5000 German university students, Moog and Backes-Gellner (2009) showed that the students tend to be overconfident in their knowledge of labour market regulations and that their perceptions often deviate from the actual regulations. These misperceptions greatly affected students' willingness to become self-employed. The widespread instance of small business exemptions could potentially also be a factor here. A study by Venn (2009), which covered small business exemptions in many of the countries in our sample, showed that the exemptions can be quite far reaching. For instance, in Germany, firms with ten or fewer employees are exempt from regular employment protection legislation; in Italy, firms with less than 15 employees are not required to pay back pay or reinstate employees that have been unfairly dismissed, and the same goes for Turkey, but the cut-off is at 30 employees. Experienced entrepreneurs ought to have greater knowledge of the actual effects of the regulations (e.g. have fewer misperceptions and a better understanding of potential exemptions) and may as such to greater extent discount for, for their intents and purposes, superfluous regulations when making their re-entry decision. Novices, on the other hand, may, due to their inexperience, be more wary of regulatory rigidity, which offers an explanation for why our results differ from previous empirical findings on the effects of labour market regulations on entrepreneurship.

Our study further reveals employment as a key external driver of the re-entry into entrepreneurship. The positive influences of rigid labour market regulations become stronger for those employed upon entry, meaning that non-employed individuals - 'outsiders' in Lindbeck and Snower's (1986) terminology-are less likely to re-enter into entrepreneurship when labour market regulations are stringent. Also, this finding comes with policy implications. First, policies that aim to increase employment, in general, may be the most beneficial policy measure for increasing entrepreneurial activity in European countries. Second, many European countries have one-sidedly eased the employment protection for temporary contracts during the last decades, keeping the level of protection for permanent contracts largely intact. An occurrence that may have created more flexibility, yet, at same time, increased the labour market segmentation and deepened the insider-outsider divide (Blanchard and Landier 2002; Cahuc and PostelVinay 2002). This type of dualism can have a strong negative impact on already marginalised groups, especially younger individuals, who may be pushed into involuntary temporary employment (Skedinger 2011). Future research may want to pose the question to what extent this type of regulatory dualism also pushes individuals into involuntary entrepreneurship.

\subsection{Future research}

Future research may also seek to model the effects of labour market rigidity on new ventures that have 
reached various stages of growth. It is well known that 'entrepreneurs' is a heterogeneous group, with most of the entrepreneurs having no or very few employees (Davidsson and Henrekson 2002; Davidsson et al. 2006). Whilst stringent labour market regulations may discourage novice individuals with high growth expectations from engaging in entrepreneurial activities as they may hamper the growth of their firms, there is still limited evidence in regard to how labour market regulations affect entrepreneurial team formation (Held et al. 2018) and start-up growth (Bornhall et al. 2017).

Another interesting pathway for future research is to study other contingencies by which institutional conditions such as labour market regulations affect entrepreneurship. In addition to the conditional effects found for current employment status, other individual-level contingencies such as fear of failure (Ardagna and Lusardi 2010) or perceptions of entrepreneurial status (Autio et al. 2013) may shape the impact of country-level institutions on individuals' likelihood of entering into, as well as succeeding in, entrepreneurship. Incorporating other institutional contingencies in future research on habitual entrepreneurs holds promise for theoretical advancements and for more successful public policy design.

Open Access This article is distributed under the terms of the Creative Commons Attribution 4.0 International License (http:// creativecommons.org/licenses/by/4.0/), which permits unrestricted use, distribution, and reproduction in any medium, provided you give appropriate credit to the original author(s) and the source, provide a link to the Creative Commons license, and indicate if changes were made.

\section{References}

Amit, R., Muller, E., \& Cockburn, I. (1995). Opportunity costs and entrepreneurial activity. Journal of Business Venturing, 10(2), 95-106. https://doi.org/10.1016/0883-9026(94)00017-O.

Ardagna, S., \& Lusardi, A. (2010). Explaining international differences in entrepreneurship: the role of individual characteristics and regulatory constraints. In J. Lerner \& A. Schoar (Eds.), International differences in entrepreneurship (pp. 1762). Chicago: University of Chicago Press.

Åstebro, T., \& Thompson, P. (2011). Entrepreneurs, jacks of all trades or hobos? Research Policy, 40(5), 637-649. https://doi.org/10.1016/j.respol.2011.01.010.

Autio, E., \& Fu, K. (2015). Economic and political institutions and entry into formal and informal entrepreneurship. Asia Pacific Journal of Management, 32(1), 67-94. https://doi. org/10.1007/s10490-014-9381-0.
Autio, E., Pathak, S., \& Wennberg, K. (2013). Consequences of cultural practices for entrepreneurial behaviors. Journal of International Business Studies, 44(4), 334-362. https://doi. org/10.1057/jibs.2013.15.

Autor, D. H., Kerr, W. R., \& Kugler, A. D. (2007). Does employment protection reduce productivity? Evidence from US states. The Economic Journal, 117(521), 189-217.

Bassanini, A., \& Garnero, A. (2013). Dismissal protection and worker flows in OECD countries: evidence from cross-country/cross-industry data. Labour Economics, 21, 25-41. https://doi.org/10.1016/j.labeco.2012.12.003.

Bassanini, A., Nunziata, L., \& Venn, D. (2009). Job protection legislation and productivity growth in OECD countries. Economic Policy, 24(58), 349-402. https://doi.org/10.1111 j.1468-0327.2009.00221.x.

Baumol, W. J. (1990). Entrepreneurship: productive, unproductive, and destructive. Journal of Political Economy, 98(5), 893-921. https://doi.org/10.1016/0883-9026(94)00014-X.

Betcherman, G., Luinstra, A., \& Ogawa, M. (2001). Labor market regulation: international experience in promoting employment and social protection. World Bank, Social Protection Discussion Paper Series 128.

Bird, M., \& Wennberg, K. (2014). Regional influences on the prevalence of family versus non-family start-ups. Journal of Business Venturing, 29(3), 421-436. https://doi.org/10.1016 /j.jbusvent.2013.06.004.

Birley, S., \& Westhead, P. (1993). A comparison of new businesses established by "novice" and "habitual" founders in Great Britain. International Small Business Journal, 12(1), 38-60. https://doi.org/10.1177/0266242693121003.

Bjørnskov, C., \& Foss, N. (2008). Economic freedom and entrepreneurial activity: some cross-country evidence. Public Choice, 134(3-4), 307-328. https://doi.org/10.1007/978-3540-87910-7_10.

Blanchard, O., \& Landier, A. (2002). The perverse effects of partial labour market reform: fixed-term contracts in France. The Economic Journal, 112(480), F214-F244.

Boeri, T., \& Garibaldi, P. (2007). Two tier reforms of employment protection: a honeymoon effect? The Economic Journal, 117(521), F357-F385.

Bornhall, A., Daunfeldt, S.-O., \& Rudholm, N. (2017). Employment protection legislation and firm growth: evidence from a natural experiment. Industrial and Corporate Change, 26(1), 169-185. https://doi. org/10.1093/icc/dtw017.

Bosma, N. S. (2009). The geography of entrepreneurial activity and regional economic development: multilevel analyses for Dutch and European regions, Utrecht University.

Bosma, N., \& Schutjens, V. (2009). Determinants of early-stage entrepreneurial activity in European regions; distinguishing low and high ambition entrepreneurship, making the difference in local, regional and national economies: Frontiers in European Entrepreneurship Research, pp. 49-80.

Bosma, N., Coduras, A., Litovsky, Y., \& Seaman, J. (2012). GEM manual: a report on the design, data and quality control of the Global Entrepreneurship Monitor.

Botero, J., Djankov, S., La Porta, R., Lopez-de-Silanes, F., \& Shleifer, A. (2004). The regulation of labor. Quarterly Journal of Economics, 119(4), 1339-1382. https://doi. org/10.1162/0033553042476215. 
Brambor, T., Clark, T. W., \& Golder, M. (2006). Understanding interaction models: improving empirical analysis. Political Analysis, 14(1), 63-82.

Bublitz, E., Nielsen, K., Noseleit, F., \& Timmermans, B. (2015). Entrepreneurship, human capital, and labor demand: a story of signaling and matching. Available at SSRN: https://ssrn. com/abstract=2638236.

Burke, A. E., FitzRoy, F. R., \& Nolan, M. A. (2008). What makes a diehard entrepreneur? Beyond the 'employee or entrepreneur' dichotomy. Small Business Economics, 31, 93-115. https://doi.org/10.1007/s11187-007-9086-6.

Burton, M. D., Sørensen, J. B., \& Dobrev, S. D. (2016). A careers perspective on entrepreneurship. Entrepreneurship Theory and Practice, 40(2), 237-247.

Cahuc, P., \& Postel-Vinay, F. (2002). Temporary jobs, employment protection and labor market performance. Labour Economics, 9(1), 63-91. https://doi.org/10.1016/S09275371(01)00051-3.

Colombo, M. G., \& Grilli, L. (2007). Funding gaps? Access to bank loans by high-tech start-ups. Small Business Economics, 29(1/2), 25-46. https://doi.org/10.1007/s11187005-4067-0.

Davidsson, P., \& Henrekson, M. (2002). Determinants of the prevalance of start-ups and high-growth firms. Small Business Economics, 19(2), 81-104. https://doi.org/10.1023 /A:1016264116508.

Davidsson, P., Delmar, F., \& Wiklund, J. (2006). Entrepreneurship and the growth of firms. Cheltenham: Edward Elgar.

Delmar, F., Wennberg, K., \& Hellerstedt, K. (2011). Endogenous growth through knowledge spillovers in entrepreneurship: an empirical test. Strategic Entrepreneurship Journal, 6(3), 199-226.

Douglas, E., J. \& Shepherd, D. A. (2000). Entrepreneurship as a utility maximizing response. Journal of Business Venturing 15(3), 231-251.

Douglas, E. J., \& Shepherd, D. A. (2002). Self-employment as a career choice: Attitudes, entrepreneurial intentions, and utility maximization. Entrepreneurship Theory and Practice, 26(3), 81-90.

Earle, J. S., \& Sakova, Z. (2000). Business start-ups or disguised unemployment? Evidence on the character of self-employment from transition economies. Labour Economics, 7(5), 575-601. https://doi.org/10.1016 /S0927-5371(00)00014-2.

Folta, T. B., Delmar, F., \& Wennberg, K. (2010). Hybrid entrepreneurship. Management Science, 56(2), 253-269. https://doi. org/10.1287/mnsc.1090.1094.

Frid, C. J., Wyman, D. M., \& Coffey, B. (2016). Effects of wealth inequality on entrepreneurship. Small Business Economics, 47(4), 895-920. https://doi.org/10.1007/s11187-016-9742-9.

Gottschalk, S., Greene, F. J., \& Müller, B. (2017). The impact of habitual entrepreneurial experience on new firm closure outcomes. Small Business Economics, 48(2), 303-321. https://doi.org/10.1007/s11187-016-9780-3.

Held, L., Herrmann, A. M., \& van Mossel, A. (2018). How labourmarket institutions influence team formation in startup ventures. Small Business Economics, https://doi.org/10.1007 /s11187-018-0010-z

Henrekson, M., \& Johansson, D. (2008). Competencies and institutions fostering high-growth firms. Foundations and
Trends ${ }^{\circledR}$ in Entrepreneurship, 5(1), 1-80. https://doi. org/10.1561/0300000026.

Henrekson, M., \& Johansson, D. (2010). Gazelles as job creators: a survey and interpretation of the evidence. Small Business Economics, 35(2), 227-244. https://doi.org/10.1007/s11187009-9172-z.

Henrekson, M., Johansson, D., \& Stenkula, M. (2010). Taxation, labor market policy and high-impact entrepreneurship. Journal of Industry, Competition and Trade, 10(3-4), 275296. https://doi.org/10.1007/s10842-010-0081-2.

Hofmann, D. A., Griffin, M. A., \& Gavin, M. B. (2000). The application of hierarchical linear modeling to organizational research. In K. J. Klein \& S. W. J. Kozlowski (Eds.), Multilevel theory, research, and methods in organizations: foundations, extensions, and new directions (pp. 467-511). San Francisco: Jossey-Bass.

Hyytinen, A., \& Rouvinen, P. (2008). The labour market consequences of self-employment spells: European evidence. Labour Economics, 15(2), 246-271. https://doi.org/10.1016 j.labeco.2007.02.001.

Katz, J. (1992). A psychosocial cognitive model of employment status choice. Entrepreneurship Theory and Practice, 17(1), 29-36.

Kim, P. H., Aldrich, H. E., \& Keister, L. A. (2006). Access (not) denied: the impact of financial, human, and cultural capital on entrepreneurial entryin the United States. Small Business Economics, 27(1), 5-22. https://doi. org/10.1007/s11187-006-0007-x.

Kim, P. H., Wennberg, K., \& Croidieu, G. (2016). Untapped riches of meso-level applications in multilevel entrepreneurship mechanisms. The Academy of Management Perspectives, 30(3), 273-291. https://doi.org/10.5465/amp.2015.0137.

Lafontaine, F., \& Shaw, K. (2016). Serial entrepreneurship: learning by doing? Journal of Labor Economics, 34(2), 217-254.

Lazear, E. P. (2004). Balanced skills and entrepreneurship. The American Economic Review, 94(2), 208-211 http://www. jstor.org/stable/3592884.

Levie, J., \& Autio, E. (2011). Regulatory burden, rule of law, and entry of strategic entrepreneurs: an international panel study. Journal of Management Studies, 48(6), 1392-1419.

Lindbeck, A., \& Snower, D. J. (1986). Wage setting, unemployment, and insider-outsider relations. The American Economic Review, 76(2), 235-239 http://www.jstor.org/stable/1818771.

Lucas Jr., R. E. (1978). On the size distribution of business firms. The Bell Journal of Economics, 9, 508-523. https://doi. org/10.2307/3003596.

McGrath, R. G., \& MacMillan, I. C. (2000). The entrepreneurial mindset. Boston: Harvard Business School Press.

Moog, P., \& Backes-Gellner, U. (2009). The impact of labour market regulations on (potential) entrepreneurs: the case of Germany. International Journal of Entrepreneurship and Innovation Management, 10(1), 53-70. https://doi. org/10.1504/IJEIM.2009.024674.

Nyström, K. (2014). Business regulation and red tape in the entrepreneurial economy. In C. Karlsson, B. Johansson, \& R. Stough (Eds.), Agglomeration, clusters and entrepreneurship (pp. 283-300). Cheltenham: Edward Elgar.

Parker, S. C. (1997). The effects of risk on self-employment. Small Business Economics, 9(6), 515-522. https://doi.org/10.1023 /A:1007919805306. 
Parker, S. C. (2009). The economics of entrepreneurship. Cambridge: Cambridge University Press.

Parker, S. C. (2013). Do serial entrepreneurs run successively better-performing businesses? Journal of Business Venturing, 28(5), 652-666. https://doi.org/10.1016/j. jbusvent.2012.08.001.

Parker, S. C. (2014). Who become serial and portfolio entrepreneurs? Small Business Economics, 43(4), 887-898. https://doi.org/10.1007/s11187-014-9576-2.

Petrova, K. (2012). Part-time entrepreneurship and financial constraints: evidence from the panel study of entrepreneurial dynamics. Small Business Economics, 39(2), 473-493. https://doi.org/10.1007/s11187-010-9310-7.

Pierre, G., \& Scarpetta, S. (2004). Employment regulations through the eyes of employers: do they matter and how do firms respond to them? IZA Discussion Paper 1424.

Plehn-Dujowich, J. (2010). A theory of serial entrepreneurship. Small Business Economics, 35(4), 377-398. https://doi. org/10.1007/s11187-008-9171-5.

Raffiee, J., \& Feng, J. (2014). Should I quit my day job?: a hybrid path to entrepreneurship. Academy of Management Journal, 57(4), 936-963. https://doi.org/10.5465/amj.2012.0522.

Reynolds, P. D., Bosma, N., \& Autio, E. (2005). Global entrepreneurship monitor: data collection design and implementation 1998-2003. Small Business Economics, 24(3), 205-231. https://doi.org/10.1007/s11187-005-1980-1.

Román, C., Congregado, E., \& Millán, J. M. (2011). Dependent self-employment as a way to evade employment protection legislation. Small Business Economics, 37(3), 363-392. https://doi.org/10.1007/s11187-009-9241-3.

Sarasvathy, S., Menon, A., \& Kuechle, G. (2013). Failing firms and successful entrepreneurs: serial entrepreneurship as a temporal portfolio. Small Business Economics, 40(2), 417434. https://doi.org/10.1007/s11187-011-9412-x.

Schulza, M., Urbiga, D., \& Prochera, V. (2016). Hybrid entrepreneurship and public policy: the case of firm entry deregulation. Journal of Business Venturing, 31(3), 272-286. https://doi.org/10.1016/j.jbusvent.2016.01.002.

Shane, S. (2003). A general theory of entrepreneurship: the individual-opportunity nexus. Cheltenham: Edward Elgar.

Shane, S. (2009). Why encouraging more people to become entrepreneurs is bad public policy. Small Business Economics, 33(2), 141-149. https://doi.org/10.1007/s11187-009-9215-5.

Skedinger, P. (2011). Employment consequences of employment protection legislation. IFN Working Paper No. 865.
Sørensen, J. B., \& Fassiotto, M. A. (2011). Organizations as fonts of entrepreneurship. Organization Science, 22(5), 13221331. https://doi.org/10.1287/orsc.1100.0622.

Toft-Kehler, R., Wennberg, K., \& Kim, P. H. (2014). Practice makes perfect: entrepreneurial-experience curves and venture performance. Journal of Business Venturing, 29(4), 453-470. https://doi.org/10.1016/j.jbusvent.2013.07.001.

Ucbasaran, D., Westhead, P., Wright, M., \& Binks, M. (2003). Does entrepreneurial experience influence opportunity identification? The Journal of Private Equity, 7(1), 7-14.

Ucbasaran, D., Alsos, G. A., Westhead, P., \& Wright, M. (2008). Habitual entrepreneurs. Foundations and Trends in Entrepreneurship, 4(4), 309-450. https://doi.org/10.1561 /0300000014.

Urbano, D., \& Alvarez, C. (2014). Institutional dimensions and entrepreneurial activity: an international study. Small Business Economics, 42(4), 703-716. https://doi. org/10.1007/s11187-013-9523-7.

Van Stel, A., Storey, D. J., \& Thurik, A. R. (2007). The effect of business regulations on nascent and young business entrepreneurship. Small Business Economics, 28(2), 171-186. https://doi.org/10.1007/s11187-006-9014-1.

Venn, D. (2009). Legislation, collective bargaining and enforcement. OECD Social, Employment, and Migration Working Papers 89.

Von Below, D., \& Thoursie, P. S. (2010). Last in, first out?: estimating the effect of seniority rules in Sweden. Labour Economics, 17(6), 987-997. https://doi.org/10.1016/j. labeco.2010.02.007.

Westhead, P., \& Wright, M. (1998). Novice, portfolio, and serial founders: are they different? Journal of Business Venturing, 13(3), 173-204. https://doi.org/10.1016 /S0883-9026(97)90002-1.

Westhead, P. \& Wright, M. (2015). The habitual entrepreneur phenomenon. International Small Business Journal, Virtual Special Issue. 1-16.

Westhead, P., Ucbasaran, D., Wright, M., \& Binks, M. (2005). Novice, serial and portfolio entrepreneur behaviour and contributions. Small Business Economics, 25(2), 109-132. https://doi.org/10.1007/s11187-003-6461-9.

Wiklund, J., \& Shepherd, D. A. (2008). Portfolio entrepreneurship: habitual and novice founders, new entry, and mode of organizing. Entrepreneurship Theory and Practice, 32(4), 701-725. https://doi.org/10.1111/j.1540-6520.2008.00249.x. 